\title{
The effect of catheter use on vein grafting of a peripheral nerve defect: an experimental study
}

\author{
Ven grefti ile periferik sinir defektlerinin onarımında kateter kullanımının \\ sinir rejenerasyonuna etkisi: Deneysel çalışma
}

\author{
Alper Mehmet BAYRAKTAR, ${ }^{1}$ Serhat ÖZBEK, ${ }^{2}$ Mesut ÖZCAN, ${ }^{2}$ \\ Behzat NOYAN, ${ }^{3}$ İlkin ÇAVUŞOĞLU ${ }^{4}$
}

\section{BACKGROUND}

Since vein grafts have been used in the repair of nerve defects, studies regarding this procedure have accumulated, and after coming into clinical use, it was noticed that there is a problem of collapse in the vein graft.

\section{METHODS}

Forty Sprague-Dawley rats were used, divided into five groups. No surgical intervention was performed in the first group. The defect was created in the sciatic nerve in Group 2 and left unrepaired. In Group 3, the defect was repaired with a nerve graft. In Group 4, the defect was repaired with a vein graft, while in Group 5, the repair was performed using a vein graft with an inserted catheter. In order to evaluate functional recovery and nerve regeneration, walking track analysis, electrophysiologic and histomorphometric analyses were done at the end of the 12 th week.

\section{RESULTS}

Although there were no functional differences between Groups 5 and 4, comparisons regarding nerve conduction velocity demonstrated that the results obtained in Group 5 were better than those in Group 4. When the number of axons on the distal part of the sciatic nerve and mid-segment of the repaired area was taken into account, no significant difference was found between Groups 3 and 5, whereas there was a significant difference between Groups 4 and 5 .

\section{CONCLUSION}

In our study, it was experimentally shown that the problem of collapse of a vein graft occurring after its use in the reconstruction of a nerve defect can be overcome by placing a catheter into the vein graft. Consequently, this method may eliminate the need for the use of a nerve graft in selected cases.

Key Words: Peripheral nerve injury; nerve defect; vein graft.

\section{AMAÇ}

Sinir defektlerinin rekonstrüksiyonunda ven greftlerinin kullanılması ile ilgili çalışmaların artması ve bu uygulamanın klinikte kullanıma girmesiyle birlikte, ven greftinin kollabe olma sorununun ortaya çıktığı görülmüştür.

\section{GEREÇ VE YÖNTEM}

Çalışmada 40 adet Spraque-Dawley sıçan kullanıldı. Beş gruptan, 1. gruba herhangi bir cerrahi girişim yapılmadı; 2. grubun siyatik sinirinde oluşturulan defekt onarılmadan bırakıldı, 3. grupta defekt sinir grefti ile onarıldı, 4. grupta defekt ven grefti ile 5. grupta ise ven grefti ve katater birlikte kullanılarak onarım yapıldı. Birinci ve ikinci grup kontrol grubu olarak kullanıldı. Fonksiyonel iyileşmeyi, sinir rejenerasyonunu değerlendirmek amaciyla, 12. haftanın sonunda, yürüme analizi, elektrofizyolojik ve histomorfometrik analizler yapıldı.

\section{BULGULAR}

Defektin ven grefti ve katater ile onarıldığı grup (grup 5) ile grup 3 ve 4 arasında fonksiyonel açıdan fark bulunmazken, sinir iletim hızı açısından bakıldığında, 5. gruptaki sonuçlar, ven grefti ile onarım yapılan gruptan (grup 4) daha iyi bulundu. Onarım distalinden ve onarım alanının ortasından alınan siyatik sinir kesitlerindeki akson sayıs1na bakıldığında 3. ve 5. grup arasında fark bulunamazken; 4. ve 5. grup arasındaki fark anlamlıydı.

\section{SONUÇ}

$\mathrm{Bu}$ çalışma sonucunda, ven grefti ile onarılan periferik sinir yaralanmalarında görülebilen ven grefti kollapsının ven grefti içine kateter yerleştirilmesi ile aşılabileceği ve bu sayede onarımda sinir grefti kullanma ihtiyacının ortadan kalkabileceği deneysel olarak gösterilmiştir.

Anahtar Sözcükler: Periferik sinir yaralanması; sinir hasar1; ven grefti.

\footnotetext{
${ }^{1}$ Department of Plastic and Reconstructive Surgery, Çekirge State Hospital, Bursa; Departments of ${ }^{2}$ Plastic and Reconstructive Surgery, ${ }^{3}$ Physiology,
} ${ }^{4}$ Histology, Uludağ University Faculty of Medicine, Bursa, Turkey. 
The repair of a peripheral nerve injury is a challenging problem in reconstructive surgery. End-to-end repair is the first alternative, if the nerve ends can be approximated without undue tension. If there is a nerve defect, many technical procedures have been reported for the repair. Repair with autogenous nerve grafts, vascularized nerve grafts, autogenous vein grafts, use of synthetic tubes, and end-to-side nerve coaptations are the options. ${ }^{[1-3]}$

If end-to-end repair is not available, the use of a nerve graft is the gold standard in the repair of nerve defects. ${ }^{[4]}$ Although nerve grafting has superior results, it also has some donor-site morbidities and usually necessitates preparation of a distant operation site and further dissection. ${ }^{[5-7]}$

If vein graft is not the choice, or in cases of absent proximal nerve stump, end-to-side nerve coaptation has been accepted as a reliable alternative method in nerve repair. ${ }^{[8,9]}$ The main advantages of this method are to eliminate the need for a nerve graft and donor site morbidity and to locate the coaptation site and the target organ in close proximity. However, functional loss in the intact neighboring nerve that is used as a donor nerve remains controversial. ${ }^{[8,9]}$

In the repair of nerve defects, the use of a vein graft is another alternative procedure. ${ }^{[10-12]}$ In contrast to many resorbable nerve tube models, vein grafts have biologic permeability and are used as an alternative to nerve grafts in long segmental nerve defects. ${ }^{[13]}$ Biologic permeability permits diffusion of the released neurotrophic factors and prevents fibrous tissue infiltration. ${ }^{[14]}$ Since vein grafts have been used in the repair of nerve defects, studies regarding this procedure have been accumulated, and after coming into clinical use, it was found that there is a problem of collapse in the vein graft. ${ }^{[15-17]}$

The best results are achieved after the repair of 3 $\mathrm{cm}$ or smaller defects due to the collapse of longer vein grafts. ${ }^{[17]}$ Some researchers placed pieces of nerve ${ }^{[18-20]}$ and muscle tissue ${ }^{[21,22]}$ inside the vein graft to prevent the collapse of the graft, and they obtained good results in defects shorter than $3 \mathrm{~cm}$ with this combined technique. ${ }^{[18-20]}$

The aim of this study was to place a catheter inside the vein graft to prevent the collapse of the graft occurring after its use in the reconstruction of a nerve defect. By using this technique, transition of proximal regeneration to the distal part is presumed to be complete and effective.

\section{MATERIALS AND METHODS} Animal Preparation

This study was approved by the Animal Ethi- cal Committee of Uludağ University. Forty female Sprague-Dawley rats weighing 225-300 g were used and maintained under standard laboratory conditions. The rats were randomly divided into five groups for different surgical treatments, except for the group consisting of animals with non-operated sciatic nerves. There were eight rats in each group. The animals were allowed free access to rat chow and water.

\section{Surgical Procedures}

Surgery was performed using a binocular operative microscope (MTX-1H1SVI; Olympus Optical Co., Ltd., Tokyo, Japan) and microsurgical techniques. After induction of sodium pentobarbital anesthesia (Nembutal, 30-50 mg/kg intraperitoneally; Abbott Laboratories, Quebec, Canada), temporary inhalational ether was provided during the electrophysiological studies. After the anesthesia, the left hind limbs of the rats were treated in a sterile manner.

Skin and gluteal muscle were incised, and the sciatic nerve segment between the sciatic foramen and the bifurcation of tibial-peroneal branches was isolated from the neighboring tissues by separating membranous structures. The sciatic nerve was preserved at a level $7 \mathrm{~mm}$ distal to the sciatic foramen and at a level $7 \mathrm{~mm}$ proximal to its bifurcation (the common peroneal and tibial nerves). A $1.5 \mathrm{~cm}$ segment of sciatic nerve located in the middle was excised to create a nerve defect. This procedure was applied to all experimental groups except Group 1. Additionally, in Groups 4 and 5, after reaching the external jugular vein by a 3 $\mathrm{cm}$ vertical skin incision, a segment of vein $20 \mathrm{~mm}$ in length was obtained.

In Group 1, the sciatic nerves of the animals were not operated and were used to obtain normative data (Fig. 1).

In Group 2, the sciatic nerve defect was not repaired and both ends of the defect were buried into nearby muscles using nylon stitches (Fig. 1).

In Group 3, the excised nerve segment was rotated $180^{\circ}$ and sutured to its own place as a nerve graft (Fig. $1)$.

In Group 4, the nerve defect was repaired using a vein graft (Fig. 1).

In Group 5, the repair was performed by placing a catheter inside the vein graft (Fig. 1).

After the catheter was placed into the vein graft in Group 5, the distal part of the catheter was taken out distal to the graft-nerve anastomosis line. In order to be able to remove the catheter in the postoperative period, a second catheter was placed into a point close to the $\mathrm{m}$. gluteus superficialis insertion. The proximal part of each catheter was removed out of the neck by passing it through subcutaneous tissue (Fig. 2). 


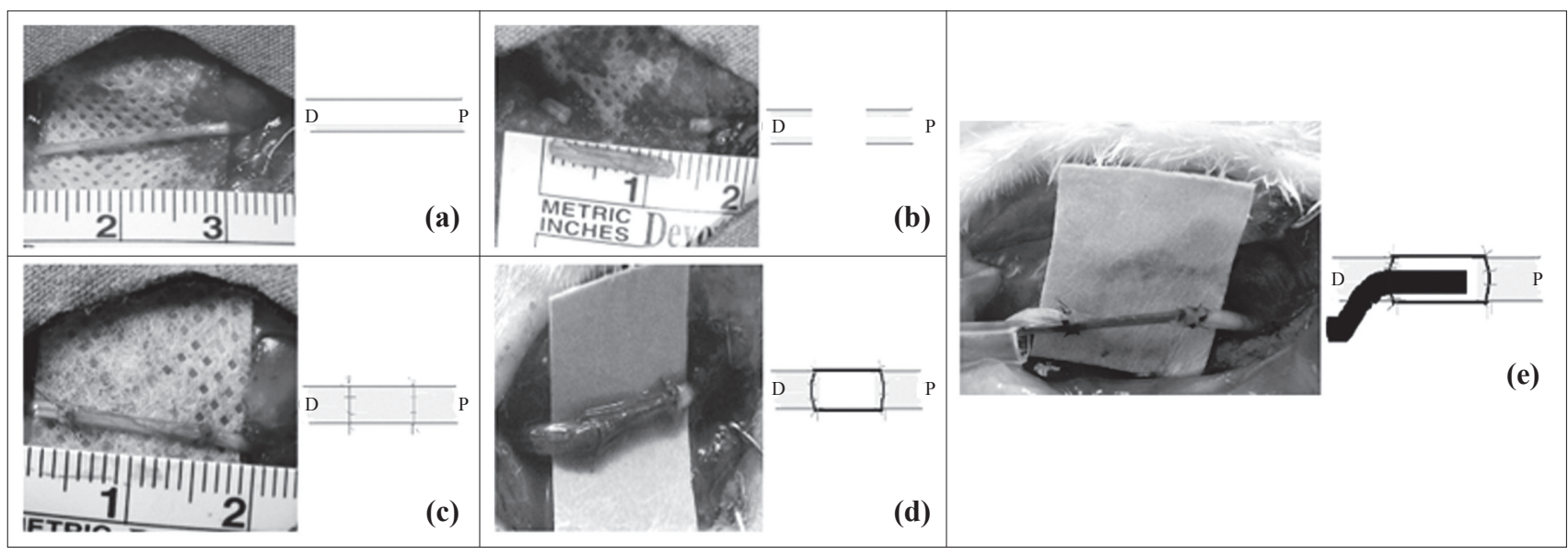

Fig. 1. Experimental Groups: (a) Group 1, non-operated sciatic nerve group, normative data was obtained, (b) Group 2, defect group that was not repaired, (c) Group 3, the excised nerve segment was rotated $180^{\circ}$ and sutured to its own place to be used as a nerve graft, (d) Group 4, nerve defect was repaired by using a vein graft, and (e) Group 5, the repair was performed placing a catheter inside the vein graft. D: Distal; P: Proximal.

After the first postoperative week, catheter no. 1 was pulled out through catheter no. 2 stepwise every second day according to the mean rate of neural regeneration in rats, which was considered to be 2.5-3 $\mathrm{mm} /$ day. $^{[23]}$ Ether anesthesia was used during this manipulation. Total removal of the catheters necessitated three steps by pulling $5 \mathrm{~mm}$ at each step, and in the third step, both catheters were removed.

All coaptations were performed using 10-0 nylon sutures. Muscle incisions were sutured with 4-0 absorbable materials, and the skin was closed with 4-0 nylon sutures.

\section{Gait Analysis}

Twelve weeks after the surgical procedures, a gait analysis was performed for all of the rats. The hind paws of each rat were soaked in methylene blue solution, and the rat was allowed to walk on a paper that had been placed on the bottom of a walking track to provide a paw print record. The procedure was repeated when the results were unsatisfactory. A sciatic functional index (SFI) was calculated for each rat using the following formula (reported by Brown et al.)::[24,25]

Sciatic Functional Index $=-38.3$ ([EPL-NPL]/
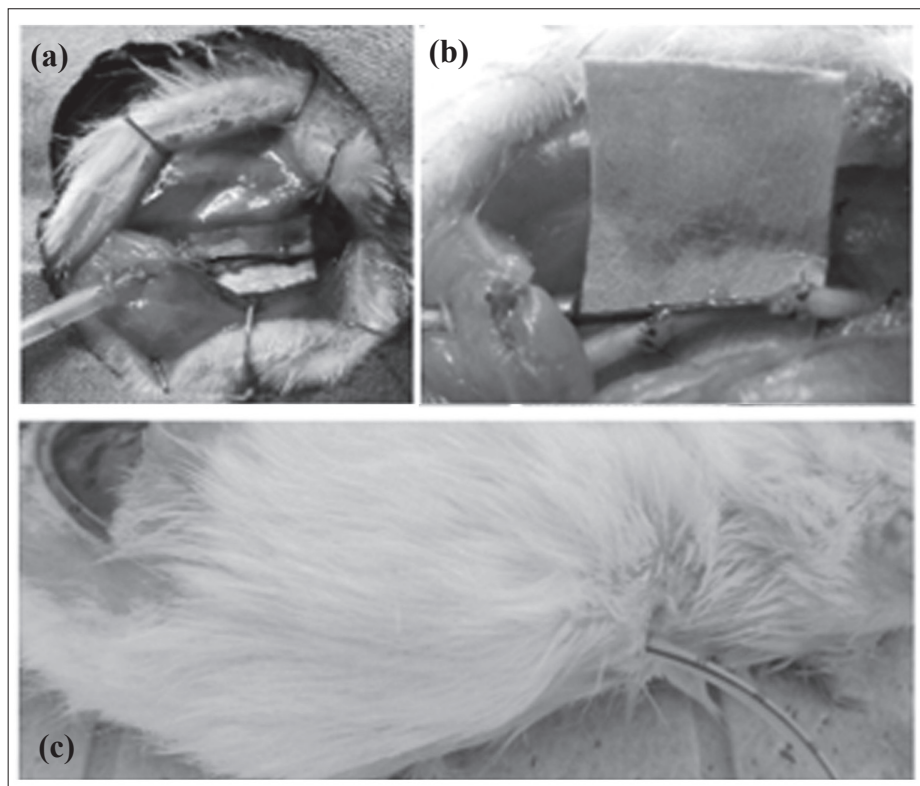

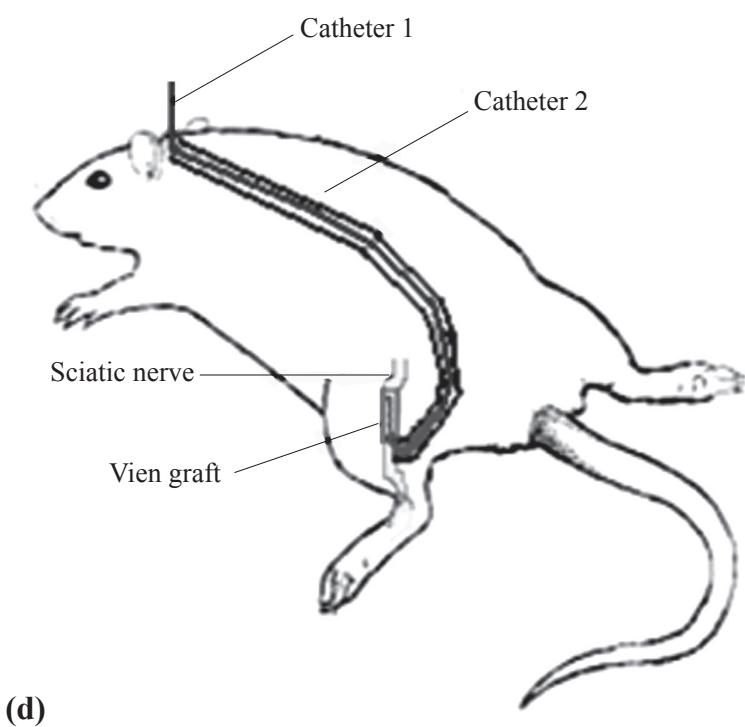

Fig. 2. The catheter used in Group 5 was placed into the vein graft, and the distal part of the catheter was taken out distal to the graft-nerve anastomosis line (a). In order to be able to remove the catheter in the postoperative period, a second catheter was placed into a point close to the $\mathrm{m}$. gluteus superficialis insertion (b). The first catheter was placed into the second catheter in order to obtain controlled removal. The proximal portion of each catheter was removed from the neck by inserting it through the subcutaneous dissection plane of rats (c). (d) A schematic drawing of this method. 
NPL $)+109.5([$ ETS-NTS]/NTS $)+13.3([$ EIT-NIT] $/$ NIT)-8.8,

Where EPL=Experimental print length, $\mathrm{NPL}=$ Normal print length, ETS=Experimental toe spread (first-fifth toe), NTS=Normal toe spread, and EIT $=$ the indices. SFIs were calculated by an investigator blinded to the experimental conditions.

An index of 0 reflects normal function and an index of -100 represents complete loss of function. ${ }^{[24-26]}$

\section{Electrophysiological Tests}

After the walking track procedure, the rats were anesthetized with temporary inhalation of ether, reincision was made on the left hind limb, and the nerves were exposed and dissected carefully. Following exposure of the nerves, nerve conduction velocity (NCV) for the sciatic nerve in each animal was measured in all groups using MP 100 data acquisition and analysis system (Biopac Systems Inc., CA, USA).

During these measurements, stimulating electrodes were placed under the sciatic nerve proximal to the suture line ( $7 \mathrm{~mm}$ away), and recorder electrodes were placed under the distal part of the sciatic nerve, at the division of tibial and peroneal nerve branches $(7 \mathrm{~mm}$ away).

Supramaximal stimulus ( $7 \mathrm{~V}, 0.5$-msec duration) generated by an MP 100 stimulator was used to stimulate the nerve, and the distance between the electrodes was measured. NCV was calculated by quotient of distance with time recorded as $\mathrm{m} / \mathrm{sec}$.

\section{Histomorphometric Assessment}

Following the electrophysiological measurements, the animals were sacrificed by high dosage of anesthetic agent and sciatic nerves were removed, $5 \mathrm{~mm}$ proximal to the proximal anastomosis line and $5 \mathrm{~mm}$ distal to the distal anastomosis line. A single nerve tissue sample was taken from Group 1; nerve tissue samples from the medial part of grafted sites as well as from proximal and distal parts were taken from all groups except for those in Group 2 (Fig. 3).

Harvested tissue samples were fixed in $4 \%$ glutaraldehyde in $0.1 \mathrm{M}$ phosphate buffer at $\mathrm{pH}$ 7.4. Each sample was then postfixed with $1 \% \mathrm{OsO}_{4}$ in $0.1 \mathrm{M}$ phosphate buffer for 2 hours, dehydrated through a graded series of ethanol, and embedded in Spurr resin (Agar Scientific, Stansted, UK). Semi-thin $(0.5 \mu \mathrm{m})$ sections of the entire nerve perpendicular to the long axis of the nerve fibers were then obtained and stained with a mixture of $1 \%$ toluidine blue and $1 \%$ borax in distilled water.

A digital camera (Cybershot DSC-F717; Sony, Tokyo, Japan) attached to a light microscope (4S-2 Alphaphot; Nikon, Tokyo, Japan) and Scion Image

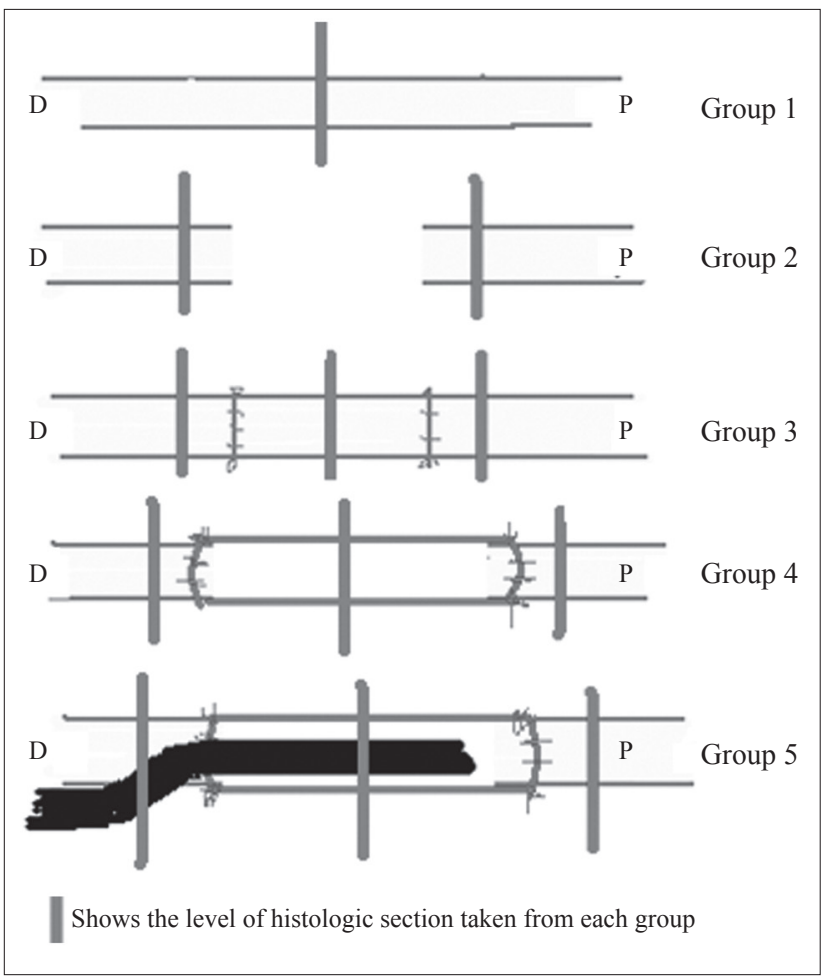

Fig. 3. Schematic drawing of experimental groups and histological sections. D: Distal; P: Proximal.

software (Scion Corp., Frederick, MD) were used to capture images, and the image analysis system was calibrated using a hemocytometer before measurements were obtained. Ten microscopic fields, selected randomly, were then captured for each nerve sample through an objective (magnification X40; Nikon, Tokyo, Japan) for accurate recognition and counting of the myelinated nerve fibers. Accounting frame of the known area was created using Scion-Image software and superimposed on the digital image to be counted. Myelinated axons were then quantified according to the unbiased counting rule ${ }^{[27]}$ and results expressed as area densities of myelinated axons (axons per square millimeter).

\section{Statistical Analysis}

Concurrency of the variable values to normal distribution was initially tested by a one-sample Kolmogorov-Smirnov test to decide whether to use parametric or nonparametric tests. Functional and electrophysiologic evaluation results and axon numbers were evaluated by Mann-Whitney U and Kruskal-Wallis tests using the Statistical Package for the Social Sciences (SPSS) 13.0 program. Pearson correlation test was used for correlation of intergroup variables with one another.

All of the quantitative results were expressed as \pm standard error and the result of $\mathrm{p}<0.05$ was considered significant in the statistical analysis. 


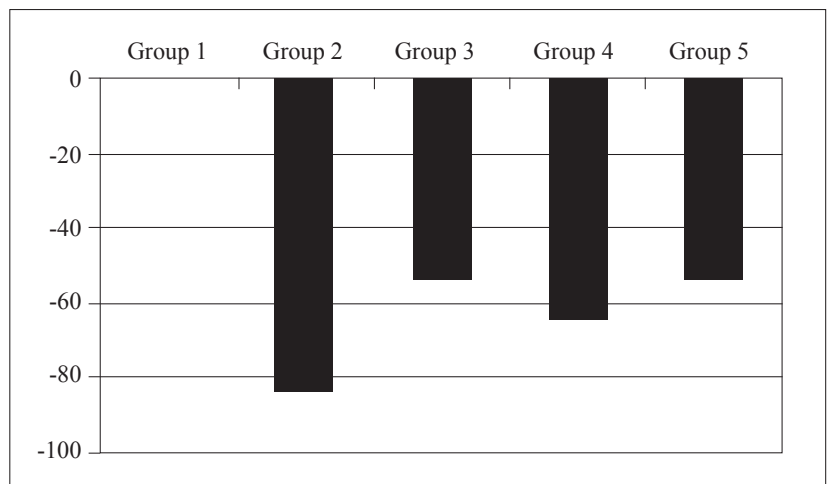

Fig. 4. Comparison with respect to Sciatic Functional Index.

\section{RESULTS}

Twelve weeks after the surgery, all of the rats in Groups A, B, C, D, and E were subjected to walking track analysis. -100 showed whole function loss and 0 showed normal function. The SFI was found as 0 in the control group (Group 1), $-83.038 \pm 6.93$ in Group 2, $-52.8 \pm 14.10$ in Group 3, $-63.33 \pm 13.26$ in Group 4, and $-53.78 \pm 20.70$ in Group 5, respectively (Fig. 4).

When groups were compared with Kruskal-Wallis test, it was found as $\mathrm{p}<0.01$, that is, at least one group was different from the others.

The groups were then evaluated among themselves using Mann-Whitney $U$ test. There were statistically significant differences between Groups 2 and 3 $(\mathrm{p}<0.01)$, Groups 2 and $4(\mathrm{p}<0.05)$ and Groups 2 and $5(\mathrm{p}<0.01)$. Conversely, no statistically significant differences were found between Groups 3 and 4, Groups 3 and 5 and Groups 4 and 5. Although the difference between Groups 4 and 5 was not found statistically important $(\mathrm{p}>0.05)$, there was a considerable difference in parameters $(\mathrm{p}=0.08)$ (Fig. 4).

Average NCV was found as $51.08 \pm 1.85$ in Group $1,43.2 \pm 1.87$ in Group 3, 42.54 \pm 2.22 in Group 4 and $50.7 \pm 3.24$ in Group 5, respectively. No NCV could be measured in Group 2 (Fig. 5). While there was a statistically significant difference between Groups 1 and 3 and Groups 1 and $4(\mathrm{p}<0.01)$, no significant difference was found between Groups 1 and 5 ( $p>0.05)$. Similarly, the difference between Groups 3 and 4 and between Groups 3 and 5 was not significant. However, the difference between Groups 4 and $5(\mathrm{p}<0.01)$ was of value (Fig. 5).

During histomorphometric evaluation, as shown in Fig. 3, different nerve tissue samples were taken from different levels in different groups. When examined in terms of proximal sections, no statistically significant difference was determined between Groups 1 and 2 with regard to mean values of myelinated axon number. At the same time, no statistically significant difference was determined between Groups 3-4 and

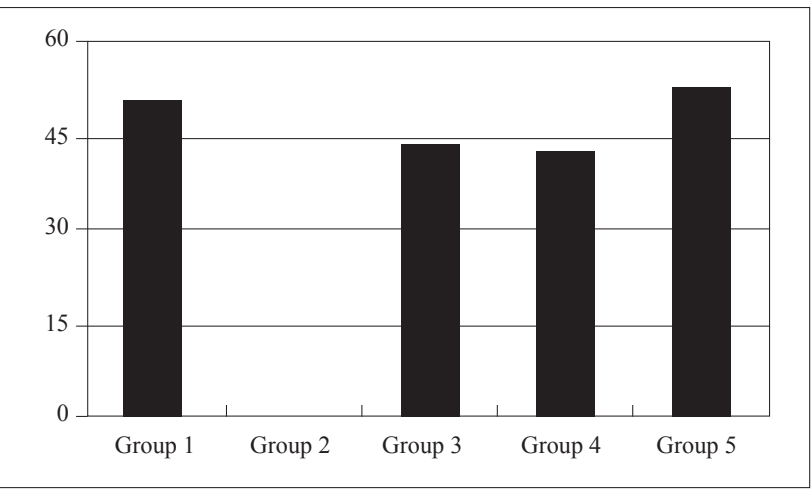

Fig. 5. Comparison with respect to nerve conduction velocities in all groups.

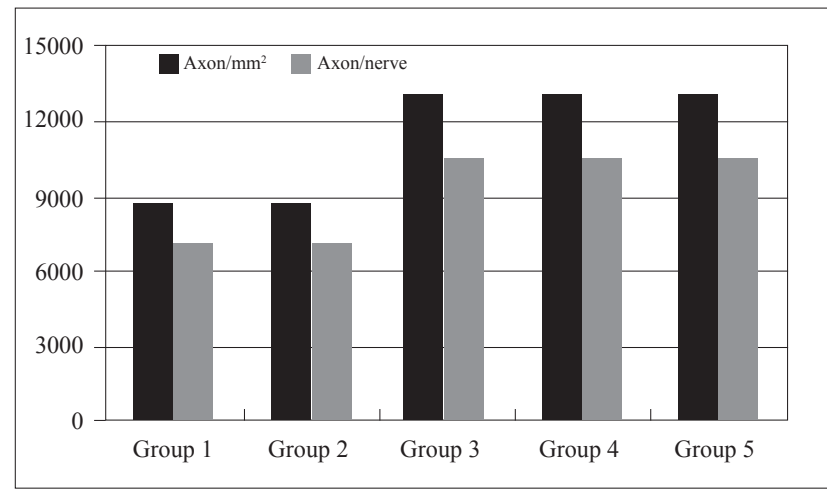

Fig. 6. Comparison of histomorphometry of sciatic nerve proximal sections.

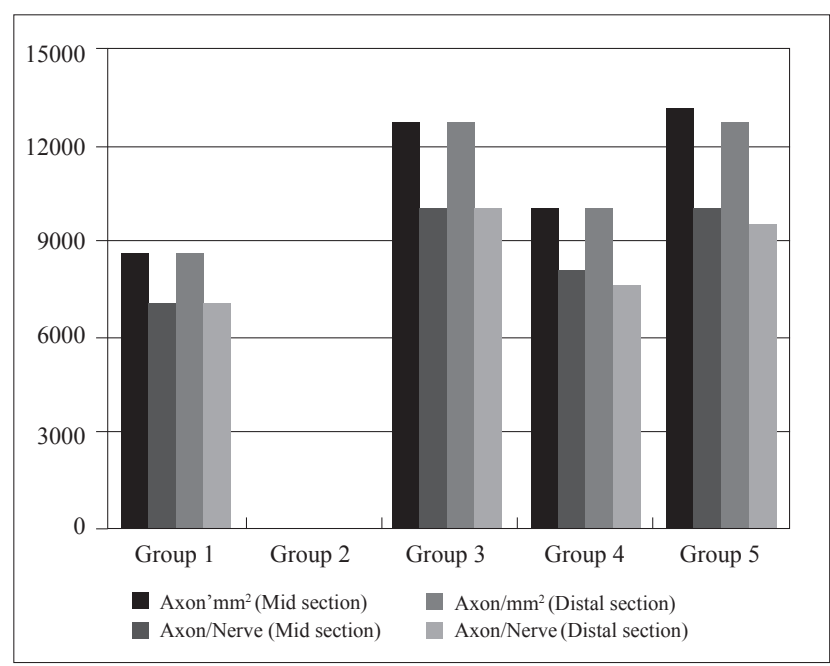

Fig. 7. Comparison with respect to histomorphometric analysis. Bar graph showing the number of myelinated axons per square millimeter and nerve unit area observed in medial and distal sections from rats in Groups 1, 3, 4, and 512 weeks after surgical procedures. (Histomorphometric analysis was not performed in Group 2 due to the lack of myelinated fibers in tissue samples from this group.)

5 ( $>0.05)$. On the contrary, the difference between Groups 1-2 and 3-4-5 was significant $(\mathrm{p}<0.05)$ (Fig. $6)$. 

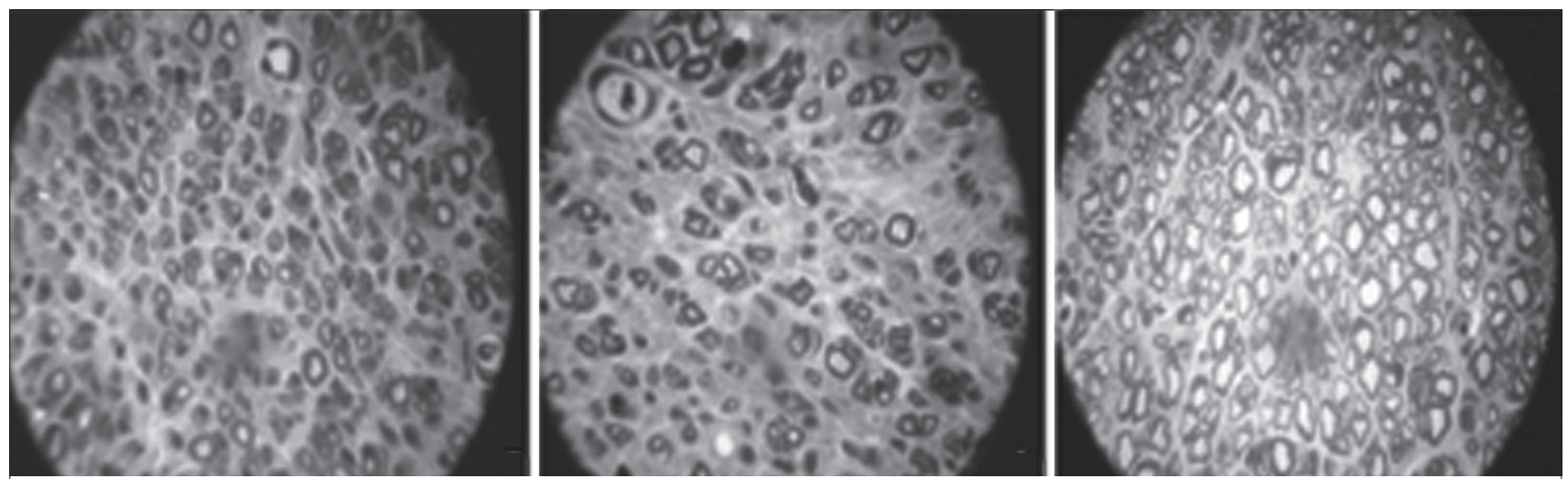

(a)
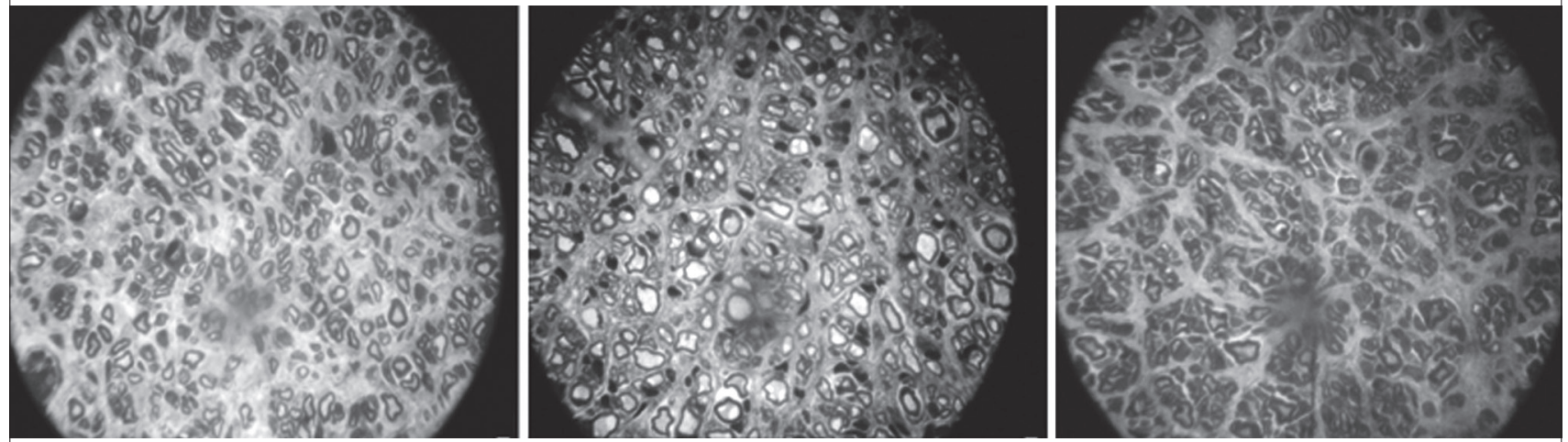

(b)

Fig. 8. Photographs of (a) medial, and (b) distal sections of Groups 3-4 and 5.

For the histomorphometry of medial and distal nerve sections, the number of myelinated axons in the sciatic nerve in Groups 3 and 5 was comparatively higher compared to the positive control group (Group 1) $(\mathrm{p}<0.001)$, but there was no significant difference between Groups 3 and 5. In Group 5, the number of myelinated axons in the distal sciatic nerve section was comparatively higher compared to Group 4, and the difference was statistically significant $(\mathrm{p}<0.05)$ (Fig. 7, 8). Similarly, the difference between Groups 3 and 4 was significant $(p<0.05)$ (Fig.7, 8). For Group 2, myelinated axons were not found in distal sciatic nerve sections, and histomorphometric analysis was not performed in this group. In Groups 3 and 5, in spite of the high number of myelinated axons in distal nerve sections, axon diameters were smaller than normal. Similarly, when the number of axons was examined in medial and distal sections for each $\mathrm{mm}^{2}$, Groups 3 and 5 had higher axon numbers compared to Group 4, which was statistically significant $(p<0.05)$ (Fig. 7, 8).

\section{DISCUSSION}

The repair of a nerve defect is one of the important problems of reconstructive surgery. Although the use of a nerve graft in the repair of a nerve defect is the main choice, ${ }^{[1-4]}$ some problems faced during acquisition of an available nerve, and resulting donor site morbidity, limit its use. ${ }^{[5-7]}$ The use of a vein graft in such defects is another preferred surgical method. ${ }^{[10]}$ As the use of vein grafts in reconstruction of a nerve defect became popular and gained a place in clinical practice, ${ }^{[10-12]}$ it was observed that vein grafts used in this procedure have a problem of collapse. ${ }^{[17]}$

Autogenic vein grafts are supportive tunnels for regeneration and maturation of nerve fibers that are experimentally and clinically proven. ${ }^{[10]}$ Developing the skeleton structure of nerve buds emerging from regenerated nerve ends, providing axonal migration, possessing extracellular matrix contents, and utilizing them with the help of growth factors, vein grafts are shown to have all conditions for nerve conduit models. ${ }^{[2]} \mathrm{Chiu}^{[10]}$ and Walton ${ }^{[11]}$ reported successful results on this subject.

Contrary to many resorbable nerve conduit models that are used for nerve defect repairs, vein grafts are alternatives for nerve grafts in long defects because of their biological permeability. This current biological permeability has an advantage of allowing the diffusion of neurotrophic factors and preventing fibrous tissue infiltration. Nowadays, the most important problem of synthetic and resorbable nerve conduit models and tissue engineers is providing biological permeability. ${ }^{[14]}$ The elastic structure of the vein prevents formation of adhesion and scar tissue and also formation of compression. 
Because vein grafts are non-immunogenic, they form less inflammatory reaction. Obtaining vein grafts is easier, they last longer than bioabsorbable nerve conduits, and they have many alternatives for diameter tunes. ${ }^{[15]}$ After nerve regeneration, because the vein is an autogenous tissue, there is no need for taking the vein out of the surgical area. ${ }^{[10]}$ The three layers of veins are rich in laminin, and this shows similarity with basal lamina that surrounds normal or traumatized nerve fibers. Laminin takes a part in adhesion, multiplication and differentiation of nerve cells. ${ }^{[16]}$ Despite all the advantages of vein grafts, the serious problem repairing nerve defects with vein grafts is collapse, especially in long defects. ${ }^{[17]}$ Some researchers used vein grafts filled with muscle tissue ${ }^{[21,22]}$ or divided nerve tissue ${ }^{[18-20]}$ to prevent collapse, but best results with this combined technique were obtained in defects that were shorter than $3 \mathrm{~cm}$.

In this experimental study, a catheter was placed into a vein graft in order to overcome the collapse problem. The rate of drawback of the catheter from the distal coaptation point was arranged due to "delaying time in scar" ${ }^{[23,28,29]}$ and nerve regeneration rate ${ }^{[23,28,29]}$ in rats and vein graft length. Therefore, we not only prevented collapse but also obtained necessary, adequate nerve tube length for the regeneration. Furthermore, by drawing the catheter back, the rate of the regeneration was not delayed and the foreign body reaction was probably reduced.

In experimental nerve repair models, histology, morphometry, electron microscopy, NCV measurement, muscle mass index, and electromyelography have been used to determine the quantity and quality of nerve regeneration. ${ }^{[24,30,31]}$ In order to determine the regeneration functionally, SFI obtained by walking analysis and peroneal functional index have been used. ${ }^{[24,30,31]}$

When our study is evaluated in terms of nerve functional index, especially the relationship between Groups 3, 4 and 5 was investigated, and groups were compared both among themselves and to control groups. Even though there was a statistically significant difference between Group 2 and Groups 3-4-5, respectively, it was accepted as an estimated result. Despite the fact that no statistically significant difference was determined among groups when comparing Groups 3-4-5, the considerable difference in parameters between Group 4 and Groups 3-5 suggests that if the study is conducted in larger series, it may change in favor of Group 3 and Group 5. Compared with other evaluation tests, SFI is the best method in the evaluation of function and clinical period since it depends on sensory and muscle function. ${ }^{[24,32]}$

Nerve conduction velocity (NCV) and morphomet- ric analysis cannot reflect functional healing, which is the main aim of peripheral nerve surgery. When epineural suture technique is performed during the repair, axons in the proximal stump sprout through the distal endoneural tube, and therefore, NCV measurement done with electrical stimulation gives a positive result. However, if the regenerated axons reaching the distal stump cannot reach the target organ, a suitable functional result will not appear, although there is an electrical flow throughout the nerve. ${ }^{[33,34]}$ When this condition is taken into account, the fact that the parameters in Group 3 and Group 5 demonstrated noticeable differences compared with Group 4 shows good promise for our study.

When the results of NCV were examined, a statistically significant difference was found between Group 1 and Groups 3 and 4 . The fact that the nerve graft of the control group was significantly good compared to that of the vein graft was not surprising. Whereas the superiority of Group 5 to the nerve graft group (Group 3) could not be shown, the statistically significant difference that could be obtained between Group 5 (catheterized vein graft group) and Group 4 (vein graft group) was of importance. The reason for this result was that the number of axons reaching the repair site and distal region in the vein graft group with catheter was more than in the vein graft group.

In histomorphometric measurements, proximal sections were examined first. No significant difference was present between Groups 1 and 2, whereas a statistically significant difference was present compared to Groups 3, 4 and 5. No statistically significant difference could be determined between Groups 3, 4 and 5 . These findings were normal as they should regenerate after nerve damage. The number of axons in the nerve in Groups 3, 4 and 5 was consistent with regeneration findings, which takes place in a damaged nerve. There were a number of myelinated axons and nerve clumps that were in smaller dimensions; axons without myelin were also present and numbered more than in the control group.

The distal and medial sections, which are of importance in terms of the result of our study, were examined with regard to the number of the axons in the nerve. Whereas no significant difference could be found between the nerve graft group (Group 3) and Group 5 in which a catheter was placed into the vein graft, it was observed that the differences between Groups 3 and 4 (vein graft group) and between Groups 5 and 4 were statistically significant. The fact that the difference occurring in favor of Group 3 between the nerve graft group (Group 3) and vein graft group (Group 4) was not present between Group 3 and Group 5 (vein graft group with catheters) is due to the positive effects of the catheter placement. 
The results in all tests, except in SFI, were in favor of nerve graft and catheterized vein graft. In this experimental study, we aimed to overcome the collapse problem of the vein graft by using an enclosed catheter. When it is considered that the problem of vein collapse usually occurs when the gap is longer than $3 \mathrm{~cm}$ (as mostly seen in clinical procedures), ${ }^{[17]}$ this study cannot contribute to the literature because the maximum length of a sciatic nerve defect cannot exceed 3 $\mathrm{cm}$ in a rat model. Unfortunately, standard scientific tests that can be used to evaluate nerve regeneration in bigger animal models, such as in dogs or monkeys, are not available. The model used in this study, in which nerve defects were repaired by placing a catheter into a vein graft, has the following advantages:

1) In cases where obtaining an ideal and extremely acceptable nerve graft is difficult, vein grafting is a procedure in which a vein graft can be obtained easily, and the technical application is easy. Diameter adaptation is not necessary, and the graft is non-immunogenic. As the vein is an autogenic tissue, it is not necessary to remove the vein from the surgical site after the completion of nerve regeneration.

2) Donor site morbidity is minimal compared to nerve grafting.

3) The collapse problem of the vein graft can be overcome by catheter placement into the vein, and it seems possible to use this technique in 3 $\mathrm{cm}$ and longer nerve defects.

4) Micro biological media occurring in the vein graft and axoplasmic fluid accumulation at the graft site are useful and valuable for nerve regeneration.

5) Compared to synthetic nerve tube models, biologic permeability of the vein graft is one of its advantages.

With this experimental study, sciatic nerve defect repair done by a vein graft with an enclosed catheter demonstrated better results compared to single vein graft application. This procedure may eliminate the need for a nerve graft to repair a peripheral nerve defect and the risk of a functional loss in the donor nerve. In cases where nerve defect repair is planned to be performed using a vein graft, the collapse problem of the vein graft, which constitutes a serious problem, may be overcome with this method. However, to date, no adequate data are present for its clinical use.

\section{REFERENCES}

1. Payne SH Jr. Nerve repair and grafting in the upper extremity. J South Orthop Assoc 2001;10:173-89.

2. Thomas MB. Nerve repair and grafting, In Green DP, Hotchkiss RN, Pederson WC, editors. Green's operative hand sur- gery. Vol 2., Philadelphia: Churchill Livingstone; 1999. p. 1381-404.

3. Sunderland S. The anatomy and physiology of nerve injury. Muscle Nerve 1990;13:771-84.

4. IJkema-Paassen J, Jansen K, Gramsbergen A, Meek MF. Transection of peripheral nerves, bridging strategies and effect evaluation. Biomaterials 2004;25:1583-92.

5. Lundborg G, Dahlin JB. Structure and function of peripheral nerve. In: Gelberman RH, editor. Operative nerve repair and reconstruction. Philadelphia: JB Lippincott; 1991. p. 3-18.

6. Lundborg G. Nerve regeneration and repair. A review. Acta Orthop Scand 1987;58:145-69.

7. Brandt KE, Mackinnon SE. Microsurgical repair of peripheral nerves and nerve grafts. In: Aston SJ, Beasley RW, Tho CHM, editors. Grabb and Smith's plastic surgery. Philadelphia: Lippincott-Raven; 1997. p. 79-90.

8. Liu K, Chen LE, Seaber AV, Goldner RV, Urbaniak JR. Motor functional and morphological findings following end-to-side neurorrhaphy in the rat model. J Orthop Res 1999;17:293300.

9. Ozbek S, Ozcan M, Noyan B, Kurt MA, Tirelioğlu S, Bozkurt $\mathrm{C}$, et al. End-to-side nerve coaptation: is an additional proximal coaptation useful when available? Ann Plast Surg 2005;55:281-8.

10. Chiu DT, Janecka I, Krizek TJ, Wolff M, Lovelace RE. Autogenous vein graft as a conduit for nerve regeneration. Surgery 1982;91:226-33.

11. Walton RL, Brown RE, Matory WE Jr, Borah GL, Dolph JL. Autogenous vein graft repair of digital nerve defects in the finger: a retrospective clinical study. Plast Reconstr Surg 1989;84:944-9; discussion 950-2.

12. Chiu DT, Strauch B. A prospective clinical evaluation of autogenous vein grafts used as a nerve conduit for distal sensory nerve defects of $3 \mathrm{~cm}$ or less. Plast Reconstr Surg 1990;86:928-34.

13. Mackinnon SE, Dellon AL. Clinical nerve reconstruction with a bioabsorbable polyglycolic acid tube. Plast Reconstr Surg 1990;85:419-24.

14. Hudson TW, Evans GR, Schmidt CE. Engineering strategies for peripheral nerve repair. Clin Plast Surg 1999;26:617-28.

15. Foidart-Dessalle M, Dubuisson A, Lejeune A, Severyns A, Manassis Y, Delree P, et al. Sciatic nerve regeneration through venous or nervous grafts in the rat. Exp Neurol 1997; 148:236-46.

16. Thanos PK, Okajima S, Terzis JK. Ultrastructure and cellular biology of nerve regeneration. J Reconstr Microsurg 1998;14:423-36.

17. Chiu DT. Autogenous venous nerve conduits. A review. Hand Clin 1999; 15:667-71.

18. Tang JB. Group fascicular vein grafts with interposition of nerve slices for long ulnar nerve defects: report of three cases. Microsurgery 1993;14:404-8.

19. Tang JB. Vein conduits with interposition of nerve tissue for peripheral nerve defects. J Reconstr Microsurg 1995;11:216.

20. Keskin M, Akbaş H, Uysal OA, Canan S, Ayyldz M, Ağar E, et al. Enhancement of nerve regeneration and orientation across a gap with a nerve graft within a vein conduit graft: a functional, stereological, and electrophysiological study. Plast Reconstr Surg 2004;113:1372-9.

21. Battiston B, Tos P, Cushway TR, Geuna S. Nerve repair by means of vein filled with muscle grafts I. Clinical results. Microsurgery 2000;20:32-6. 
22. Battiston B, Tos P, Geuna S, Giacobini- Robechi MG, Guglielmone R. Nerve repair by means of vein filled with muscle grafts. II. Morphological analysis of regeneration. Microsurgery 20: 37-41, 2000.

23. Danielsen N, Lundborg G, Frizell M. Nerve repair and axonal transport: outgrowth delay and regeneration rate after transection and repair of rabbit hypoglossal nerve. Brain Res 1986;376:125-32.

24. Varejão AS, Meek MF, Ferreira AJ, Patrício JA, Cabrita AM. Functional evaluation of peripheral nerve regeneration in the rat: walking track analysis. J Neurosci Methods 2001;108:1-9.

25. Brown CJ, Mackinnon SE, Evans PJ, Bain JR, Makino AP, Hunter DA, et al. Self-evaluation of walking-track measurement using a Sciatic Function Index. Microsurgery 1989; 10:226-35.

26. Hare GM, Evans PJ, Mackinnon SE, Best TJ, Bain JR, Szalai JP, et al. Walking track analysis: a long-term assessment of peripheral nerve recovery. Plast Reconstr Surg 1992;89:2518.

27. Mayhew TM. A review of recent advances in stereology for quantifying neural structure. J Neurocytol 1992;21:313-28.
28. Lundborg G. A 25-year perspective of peripheral nerve surgery: evolving neuroscientific concepts and clinical significance. J Hand Surg Am 2000;25:391-414.

29. Amara B, de Medinaceli L, Lane GB, Merle M. Functional assessment of misdirected axon growth after nerve repair in the rat. J Reconstr Microsurg 2000;16:563-7.

30. Al-Qattan MM. Terminolateral neurorrhaphy: review of experimental and clinical studies. J Reconstr Microsurg 2001;17:99-108.

31. Bain JR, Mackinnon SE, Hunter DA. Functional evaluation of complete sciatic, peroneal, and posterior tibial nerve lesions in the rat. Plast Reconstr Surg 1989;83:129-38.

32. Weber RA, Warner MR, Verheyden CN, Proctor WH. Functional evaluation of gap vs. abutment repair of peripheral nerves in the rat. J Reconstr Microsurg 1996;12:159-63.

33. Giovanoli P, Koller R, Meuli-Simmen C, Rab M, Haslik W, Mittlböck M, et al. Functional and morphometric evaluation of end-to-side neurorrhaphy for muscle reinnervation. Plast Reconstr Surg 2000;106:383-92.

34. Kanaya F, Firrell JC, Breidenbach WC. Sciatic function index, nerve conduction tests, muscle contraction, and axon morphometry as indicators of regeneration. Plast Reconstr Surg 1996;98:1264-74. 